\title{
Pharmacogenetics of CYP3A5 on Carbamazepine pharmacokinetics in epileptic patients developing toxicity
}

\author{
Mubarak Al-Gahtany ${ }^{1 *}$, Gauthaman Karunakaran², Murali Munisamy ${ }^{2^{*}}$ \\ From 2nd International Genomic Medical Conference (IGMC 2013) \\ Jeddah, Kingdom of Saudi Arabia. 24-27 November 2013
}

\section{Background}

The genetically polymorphic cytochrome P450 enzymes are involved in the metabolism and elimination of a number of widely used drugs. CYP3A5 exhibits remarkable inter-individual differences in the pharmacokinetics of Carbamazepine [1]. The present study was undertaken to investigate the effects of CYP3A5 on the pharmacokinetics of antiepileptic drug Carbamazepine in the epileptic patients showing toxicity.

\section{Materials and methods}

30 epileptic individuals who had developed toxicity to carbamazepine and 30 control epileptic subjects who had not developed toxicity to carbamazepine were genotyped for CYP3A5 polymorphisms by polymerase chain reactionrestriction fragment length polymorphisms (PCR-RFLP Method). Carbamazepine plasma levels were analyzed by reversed phase HPLC method and pharmacokinetic parameters such as area under the concentration curve (AUC), maximum concentration (Cmax), time to Cmax (tmax) and half-life ( $\mathrm{t} 1 / 2)$ were estimated by non-compartmental analysis using PK SOLUTIONS ${ }^{\circledR}$ software.

\section{Results}

A significant correlation was observed in the frequency of homozygous CYP3A5 mutant allele $(\mathrm{P}<0.01)$ among the carbamazepine toxicity and controls. The pharmacokinetics parameters of carbamazepine in homozygous mutant group showed longer half-life $(\mathrm{t} 1 / 2=17 \mathrm{hrs})$ and

\footnotetext{
* Correspondence: muralimunisamy@gmail.com

${ }^{1}$ Faculty of Neuro Surgery, King Khalid University, Abha, KSA

2Department of Pharmacology, College of Pharmacy, King Khalid University, Abha, KSA
}

Full list of author information is available at the end of the article less clearance rate $(\mathrm{CL}=1.5 \mathrm{~L} / \mathrm{hr})$ when compared to wild type group $(\mathrm{t} 1 / 2=12.8 \mathrm{hrs}, \mathrm{CL}=2.9 \mathrm{~L} / \mathrm{hr})$.

\section{Conclusions}

Our findings suggest that the CYP3A5 Genetic Polymorphisms plays a significant role in the steady state concentrations of carbamazepine and thereby having impact on toxicity in epileptic patients.

Authors' details

${ }^{1}$ Faculty of Neuro Surgery, King Khalid University, Abha, KSA. ${ }^{2}$ Department of Pharmacology, College of Pharmacy, King Khalid University, Abha, KSA.

Published: 2 April 2014

\section{Reference}

1. Puranik YG, Birnbaum AK, Marino SE, Ahmed G, Cloyd JC, Remmel RP, Leppik IE, Lamba JK: Association of carbamazepine major metabolism and transport pathway gene polymorphisms and pharmacokinetics in patients with epilepsy. Pharmacogenomics 2013, 14(1):35-45.

doi:10.1186/1471-2164-15-S2-P2

Cite this article as: Al-Gahtany et al:: Pharmacogenetics of CYP3A5 on Carbamazepine pharmacokinetics in epileptic patients developing toxicity. BMC Genomics 2014 15(Suppl 2):P2.

Submit your next manuscript to BioMed Central and take full advantage of:

- Convenient online submission

- Thorough peer review

- No space constraints or color figure charges

- Immediate publication on acceptance

- Inclusion in PubMed, CAS, Scopus and Google Scholar

- Research which is freely available for redistribution
C Biomed Central

(c) 2014 Al-Gahtany et al; licensee BioMed Central Ltd. This is an Open Access article distributed under the terms of the Creative Commons Attribution License (http://creativecommons.org/licenses/by/2.0), which permits unrestricted use, distribution, and reproduction in any medium, provided the original work is properly cited. 